\title{
Charcoal anatomy of Brazilian species. I. Anacardiaceae
}

\author{
THAÍS A.P. GONÇALVES ${ }^{1}$ and RITA SCHEEL-YBERT ${ }^{2}$
}

\author{
${ }^{1}$ Universidade Federal do Paraná, Departamento de Engenharia e Tecnologia Florestal, \\ Av. Pref. Lothário Meissner, 900, Jardim Botânico, 80210-170 Curitiba, PR, Brasil \\ ${ }^{2}$ Programa de Pós-Graduação em Arqueologia, Museu Nacional, Universidade Federal do \\ Rio de Janeiro, Departamento de Antropologia, Laboratório de Arqueobotânica e Paisagem, \\ Quinta da Boa Vista, s/n, São Cristóvão, 20940-040 Rio de Janeiro, RJ, Brasil
}

Manuscript received on June 18, 2015; accepted for publication on November 27, 2015

\begin{abstract}
Anthracological studies are firmly advancing in the tropics during the last decades. The theoretical and methodological bases of the discipline are well established. Yet, there is a strong demand for comparative reference material, seeking for an improvement in the precision of taxonomic determination, both in palaeoecological and palaeoethnobotanical studies and to help preventing illegal charcoal production. This work presents descriptions of charcoal anatomy of eleven Anacardiaceae species from six genera native to Brazil (Anacardium occidentale, Anacardium parvifolium, Astronium graveolens, Astronium lecointei, Lithrea molleoides, Schinus terebenthifolius, Spondias mombin, Spondias purpurea, Spondias tuberosa, Tapirira guianensis, and Tapirira obtusa). They are characterized by diffuse-porous wood, vessels solitary and in multiples, tyloses and spiral thickenings sometimes present; simple perforation plates, alternate intervessel pits, rounded vessel-ray pits with much reduced borders to apparently simple; parenchyma paratracheal scanty to vasicentric; heterocellular rays, some with radial canals and crystals; septate fibres with simple pits. These results are quite similar to previous wood anatomical descriptions of the same species or genera. Yet, charcoal identification is more effective when unknown samples are compared to charred extant equivalents, instead of to wood slides.
\end{abstract}

Key words: anthracology, archaeobotany, charcoal, palaeoecology, environmental conservation, wood anatomy.

\section{INTRODUCTION}

Charcoal, frequent in archaeological or geological contexts, is an important proxy to the reconstruction of past vegetation and climate, as well as to palaeoethnobotanical interpretations.

Anthracology, the identification of charcoal based on wood anatomical characters, is a discipline primarily developed for palaeovegetation studies related to archaeology, palaeoecology, geology, and others (Chabal 1997, Scheel-Ybert 2004a, Scott and Damblon 2010). It also applies for archaeobotany and for the identification of contemporary unknown charcoal, in which case it can be used for charcoal control.

Correspondence to: Rita Scheel-Ybert

E-mail: scheelybert@mn.ufrj.br 
At present, Brazil is the world's largest producer of charcoal, but a great part of this production still comes from illegal logging of native species (FAO 2014). Almost $90 \%$ of charcoal's production goes to the iron and steel industry (Brasil 2012) - around 30-35\% of the total output of this production comes from native species (IBGE 2010, ABRAF 2013). Frequently, this illegal production is associated with criminal acts against human beings, often including children and workers under slave-like conditions (Carneiro 2008, IOS 2011a, b). Besides, the production of illegal charcoal is responsible for the emission of c. 5 tons of carbon dioxide caused by improper removal of trees and released gases from carbonization (ABRAF 2009). Controlling charcoal production is therefore very important.

Up to recently, it was virtually impossible for government agents to verify if charcoal loads corresponded indeed to legal extraction of reforested woods or to illegal exploitation of native vegetation. However, this can be done through anthracological analysis (Gonçalves and Scheel-Ybert 2012). Usually, species from exotic genera of distinctive wood and charcoal anatomy, such as Corymbia and Eucalyptus, are cultivated for charcoal production (Gonçalves et al. 2014). Although some agroforestry managed native species can also be legally used (Friederichs et al. 2015), most native species are still illegally exploited. An official document (DOF) containing information about the charcoal origin and the species used to produce it must accompany each charcoal load. Verifying the exactitude of this information depends on the direct verification of the load by inspection agents (Gonçalves and Scheel-Ybert 2012). Hence the importance of recognizing the charcoal anatomy of native species.

In Mediterranean and temperate regions, areas of lower plant diversity, wood anatomy is better known and charcoal identification is usually based on the consultation of atlases (e.g. Greguss 1959, Schweingruber 1990, Vernet et al. 2001). However, despite numerous studies (e.g. Détienne and Jacquet 1983, Mainieri and Chimelo 1989, Barros and Callado 1997, Barros et al. 2001, 2008, Sonsin et al. 2014), wood anatomy of Brazilian species is still incompletely known, especially for extra-Amazonian and non-commercial timber species, and there are heretofore only unpublished studies on charcoal anatomy of extant species (e.g. Gonçalves 2006, 2010, Albuquerque 2012, Pinto 2013).

There is, therefore, a strong demand for anthracological studies of tropical species aiming at charcoal identification, both in the academic fields of archaeobotany, palaeoecology and others, and concerning Brazilian governmental institutions such as Serviço Florestal Brasileiro, IBAMA (Instituto Brasileiro do Meio Ambiente e dos Recursos Naturais Renováveis), Polícia Militar Ambiental, and INEA (Instituto Estatual do Ambiente), due to the economic importance of charcoal commerce and especially environmental conservation. With the purpose of improving the anatomical knowledge on tropical species and assisting microscopic charcoal identification, we investigate the wood anatomy of carbonized samples from species of the rich Brazilian flora. In this paper, we present results for native species from the Anacardiaceae family. This family is widely distributed in the tropical zone, including about 700 species from 70 genera all around the world (Souza and Lorenzi 2008), with few representatives in temperate regions (Gupta and Agarwal 2008). It comprises trees, shrubs, and rarely woody climbers and herbs (Souza and Lorenzi 2008). Many species are of a considerable economic value, producing edible fruits, chemical compounds used in industry (gums, resins, tannins, and dyes) or medicine, and quality timbers of commercial importance (Record and Hess 1943, Paula and Alves 1997). In spite of the impossibility to cover all Brazilian species comprehensively, we expect that this initiative will provide useful information to researchers of different expertise, including forest sciences, environmental conservation, wood technology, wood anatomy, palaeoecology, and palaeoethnobotany. 


\section{MATERIALS AND METHODS}

Twenty-three wood samples of 11 species from six genera of Anacardiaceae native to Brazil were described: Anacardium (A. occidentale L., A. parvifolium Ducke), Astronium (A. graveolens Jacq, A. lecointei Ducke), Lithrea (L. molleoides (Vell.) Engl.), Schinus (S. terebenthifolius Raddi), Spondias (S. mombin L., S. purpurea L., S. tuberosa Arruda), and Tapirira (T. guianensis Aubl., T. obtusa (Benth.) J.D.Mitch.). Wood samples were obtained from field sampling and institutional wood collections: Jardim Botânico do Rio de Janeiro, Rio de Janeiro, Brazil (RBw); Instituto de Pesquisas Tecnológicas, São Paulo, Brazil (BCTw); Instituto Florestal, São Paulo, Brazil (SPSFw). Wood samples collected by R. Scheel-Ybert (RS) are vouchered in Herbarium Alberto Castellanos, Rio de Janeiro, Brazil (GUA); duplicates are deposed in RBw and BCTw wood collections. Specialists identified the material collected by M.E. Solari (ME), although unvouchered. In all cases, samples from the trunk or large branches were analyzed, except for two samples of small branches (Astronium graveolens - ME102, ME109). Samples were wrapped in aluminum foil and carbonized in a muffle furnace at $400{ }^{\circ} \mathrm{C}$ during 40 minutes. All samples are deposited in the charcoal collection of the National Museum at Rio de Janeiro (Antracoteca do Museu Nacional - Laboratório de Arqueobotânica e Paisagem, Universidade Federal do Rio de Janeiro, Brazil). The charring temperature chosen is the same as in many scientific studies based on charcoal analyses (e.g. Solari 1993, Prior and Gasson 1993, Scheel-Ybert 2004b, Gonçalves et al. 2012).

Charcoal samples were manually split according to the fundamental wood sections (transversal, longitudinal tangential, and longitudinal radial sections) and examined under a reflected light brightfield/ darkfield microscope. Descriptions followed the recommended procedures and terminology by the International Association of Wood Anatomist (IAWA Committee 1989), except for intervessel pits size, for which the internal horizontal diameter of pit apertures was measured (Scheel-Ybert and Gonçalves in press). Anthracologists conventioned to measure the pit aperture (but measuring also the pit chamber diameter when possible) because the carbonization process induces wood cell walls homogenization, frequently making pit chambers indistinguishable. The pit aperture, however, is always distinct.

For quantitative measurements, arithmetic means and amplitude (minimum and maximum values) are given. Micrographs were taken using a JEOL 6300F SEM at University Montpellier II (UM-II, France), a JEOL 5310 at the Institut of Biophysics of the Federal University of Rio de Janeiro (UFRJ, Brazil), and a Leica S440 SEM at the Center of Mineral Technology (CETEM, Brazil). Some authors argued that charcoal is sufficiently conductive to be suitable for SEM studies without any special coating or preparation (Blankenhorn et al. 1972, Cutter et al. 1980). However, we have obtained better results by previously sputter-coating specimens with gold or platinum.

\section{RESULTS}

Wood anatomical descriptions for each genus follow. The most important anatomical features of the studied species are presented in Table I.

\section{Anacardium (L.) Rottboell (Fig. 1 a-c)}

Material studied: A. occidentale L. (Rio de Janeiro, Brazil - RS 19); A. parvifolium Ducke (Amazonas, Brazil - BCTw 17084).

Growth rings: boundaries indistinct or absent. Vessels: wood diffuse-porous; solitary (60\%), in multiples of $2(30 \%)$ and of $3(10 \%)$; tangential diameter $175(110-260) \mu \mathrm{m} ; 8(4-14)$ vessels $/ \mathrm{mm}^{2}$; tyloses common in 
A. occidentale; perforation plates simple with oblique or horizontal end walls; intervessel pits alternate, 7(49) $\mu \mathrm{m}$; vessel-ray pits larger than intervessel pits, with much reduced borders to apparently simple, rounded. Axial parenchyma: scanty paratracheal or vasicentric, sometimes confluent, in 2-4-celled strands. Rays: 1-2-seriate in A. occidentale, exclusively 1 -seriate in A. parvifolium; $10(9-13)$ rays $/ \mathrm{mm}$; body ray cells procumbent with one row of upright and square marginal cells in $A$. occidentale and body cells procumbent with variable thickness and 1-3 rows of upright and square marginal cells in A. parvifolium. Fibres: septate with bordered pits and very thin walls. Secretory elements: absent. Mineral inclusions: absent.

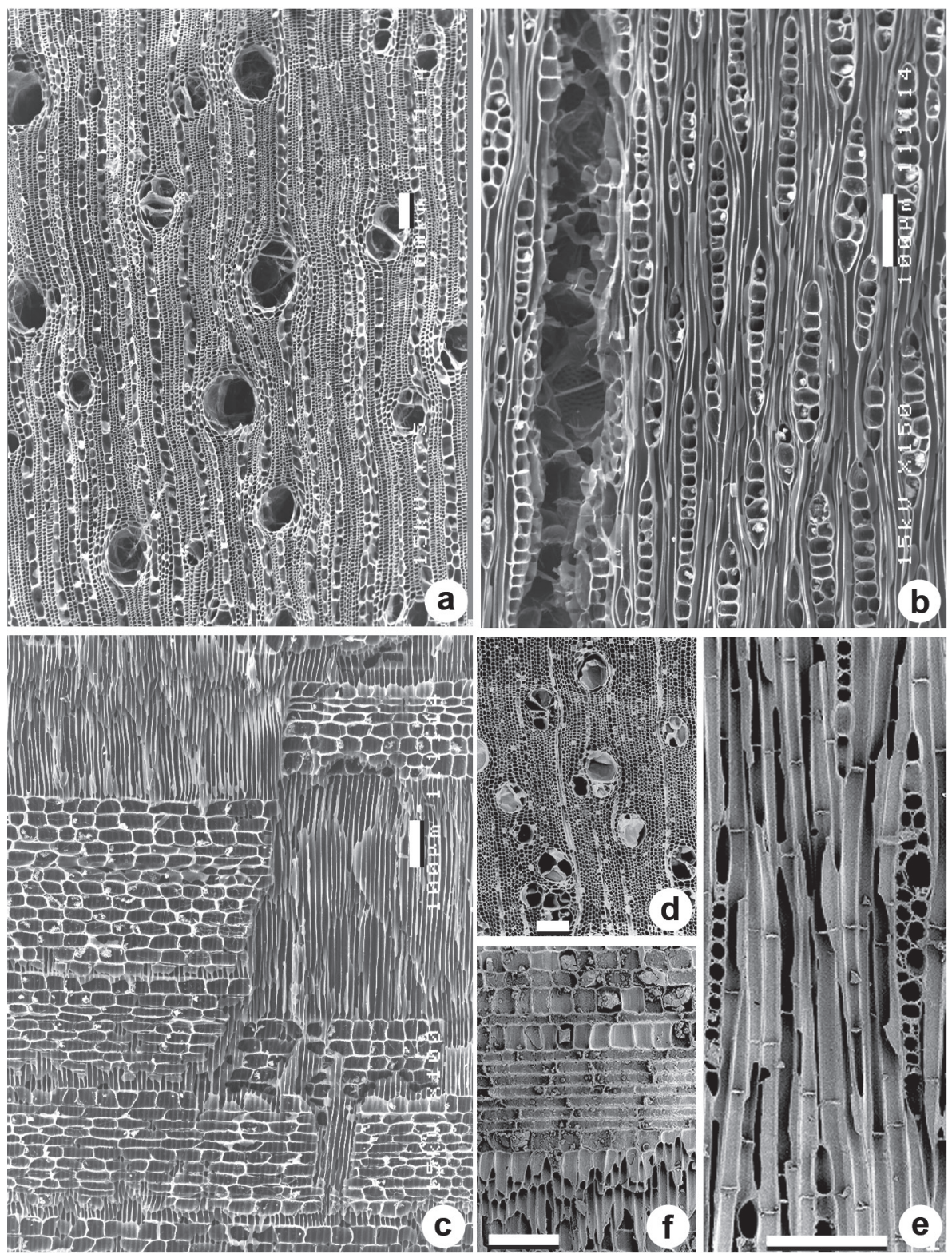

Figure 1. a-c. Anacardium occidentale (BCTw 12687). Uncoated, IBCCF/UFRJ. - d-f. Astronium lecointei (RBw 6708), platinum-coated, UM-II. - a,d: Transverse section. - b,e: Tangential section - c,f: Radial section. Bars $=100 \mu \mathrm{m}$. 
Astronium Jacq. (Fig. 1 d-f, Fig. 2)

Material studied: A. graveolens Jacq (Espírito Santo, Brazil - BCTw 13545, SPSFw 436; Mato Grosso, Brazil - ME 102, ME 109); A. lecointei Ducke (Pará, Brazil - RBw 6708).

Growth rings: boundaries marked by thick-walled latewood fibres in A. graveolens, and indistinct or absent in A. lecointei. Vessels: wood diffuse-porous; solitary (70\%), in multiples of 2 (25\%) and $3(5 \%)$; in A. graveolens [SPSFw 436] vessels are exclusively solitary; tangential diameter 90(40-130) $\mu \mathrm{m} ; 15(12-25)$ vessels $/ \mathrm{mm}^{2}$; tyloses present; perforation plates simple with oblique or horizontal end walls; intervessel pits alternate, 5(4-10) $\mu \mathrm{m}$; vessel-ray pits larger than intervascular pits, with much reduced borders to apparently simple, rounded. Axial parenchyma: scanty paratracheal and rarely vasicentric, in 1-4-celled strands. Rays 1-3-seriate in A. graveolens, 1-, rarely 2-seriate in A. lecointei; 8(7-11) rays $/ \mathrm{mm}$; body ray cells procumbent with 1 to 4 rows of upright and square marginal cells. Fibres: septate with simple to bordered pits and very thin-walled. Secretory elements: radial canals with tangential diameter 30(10-70) $\mu \mathrm{m}$. Mineral inclusions: prismatic crystals in ray cells.

\section{Lithrea Miers ex Hook \& Arn. (Fig. 3)}

Material studied: L. molleoides (Vell.) Engl. (Paraná, Brazil - BCTw 8743; São Paulo, Brazil - BCTw 134, RBw 1710).

Growth rings: boundaries indistinct or absent. Vessels: wood diffuse-porous; solitary (35\%), in multiples of $2(35 \%), 3(15 \%)$, and 4-6 (13\%); tangential diameter $45(20-80) \mu \mathrm{m}$; frequency vary from 40(25-60) [BCTw 134, BCTw 8743] to 95(70-110) [RBw 1710] vessels $/ \mathrm{mm}^{2}$; tyloses absent; perforation plates simple and scalariform with few bars, with oblique and horizontal end walls; intervessel pits alternate, 3,5(3-5) $\mu \mathrm{m}$; vessel-ray pits larger than intervessel pits, with much reduced borders to apparently simple, rounded; helical thickenings present in some vessels. Axial parenchyma: scanty paratracheal and vasicentric, in 1-4-celled strands. Rays: 1-3-seriate; 9(5-13) rays/mm; body ray cells procumbent with 1 to 4 rows of upright and square marginal cells. Fibres: septate with simple to bordered pits and very thin-walled. Secretory elements: absent. Mineral inclusions: prismatic crystals in fibres and ray cells [BCTw 8743, RBw 710]; crystals in radial alignment in chambered cells [BCTw 134, RBw 1710].

\section{Schinus L. (Fig.4 a-d)}

Material studied: S. terebinthifolius Raddi (Mato Grosso, Brazil - ME 165; Paraná - BCTw 868; Pernambuco, Brazil - BCTw 12733; Rio de Janeiro, Brazil - RS 05, RS 43; São Paulo, Brazil - SPSFw 479).

Growth rings: boundaries indistinct or absent. Vessels: wood diffuse-porous; solitary (14\%), in multiples of 2 (27\%), 3 (19\%), 4-8 (40\%); tangential diameter 50(20-100) $\mu \mathrm{m} ; 130(70-230)$ vessels $/ \mathrm{mm}^{2}$; tyloses common in some specimens [SPSFw 479, RS 05]; perforation plates simple with oblique and horizontal end walls; intervessel pits alternate, 3,5(2-6) $\mu \mathrm{m}$; vessel-ray pits larger than intervessel pits, with much reduced borders to apparently simple, rounded; helical thickenings present. Axial parenchyma: scanty paratracheal, fairly distinct, in 1-3-celled strands. Rays: 1-3-seriate; 10(5-15) rays/mm; body ray cells procumbent with 1 to 2 rows of upright marginal cells. Fibres: septate with simple to slightly bordered pits and very thin walls; helical thickenings sometimes present. Secretory elements: Radial canals with tangential diameter 50(30-100) $\mu \mathrm{m}$. Mineral inclusions: prismatic crystals in ray cells. 

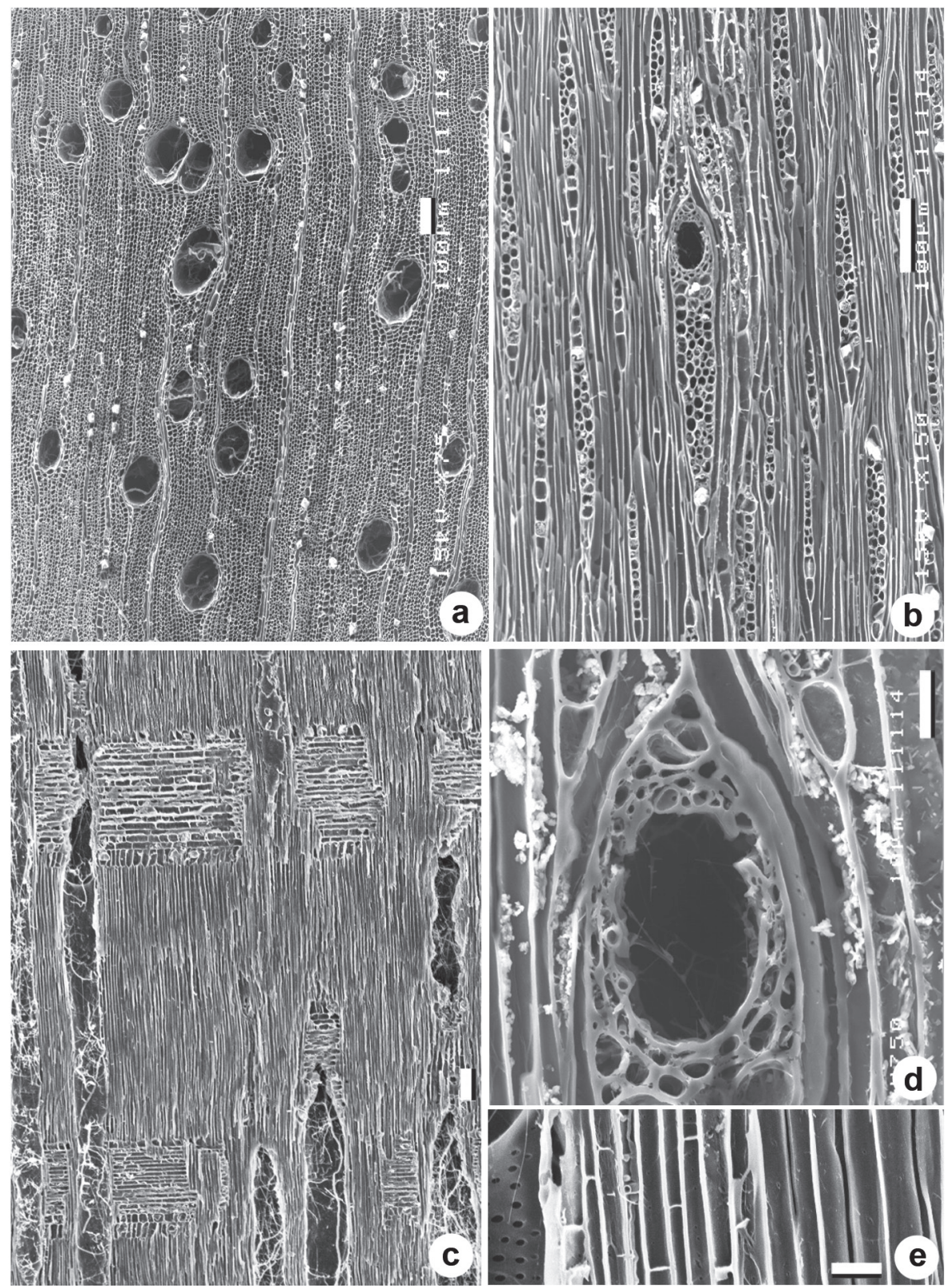

Figure 2. Astronium graveolens (RBw 3733). Uncoated, IBCCF/UFRJ. - a: Transverse section. - b: Tangential section - c: Radial section. - d: Radial canal. - e: Septate fibres. Bars = $100 \mu \mathrm{m}(\mathbf{a - c})$ and $20 \mu \mathrm{m}(\mathbf{d}-\mathbf{e})$.

\section{Spondias L. (Fig. 5)}

Material studied: S. mombin L. (Brazil - BCTw 13527); S. purpurea L. (Mato Grosso, Brazil - ME 179); S. tuberosa Arruda (Bahia, Brazil - RBw 6322, Pernambuco, Brazil - BCTw 18770).

Growth rings: boundaries indistinct or absent. Vessels: wood diffuse-porous; solitary (55\%), in multiples of 2 (35\%), and 3 (10\%); tangential diameter 135(60-250) $\mu \mathrm{m}$; 15(5-30) vessels $/ \mathrm{mm}^{2}$; tyloses absent in S. tuberosa, present in the other species; perforation plates simple with oblique and horizontal end walls; intervessel pits alternate, 7(5-10) $\mu \mathrm{m}$; vessel-ray pits larger than intervessel pits, with much reduced borders 

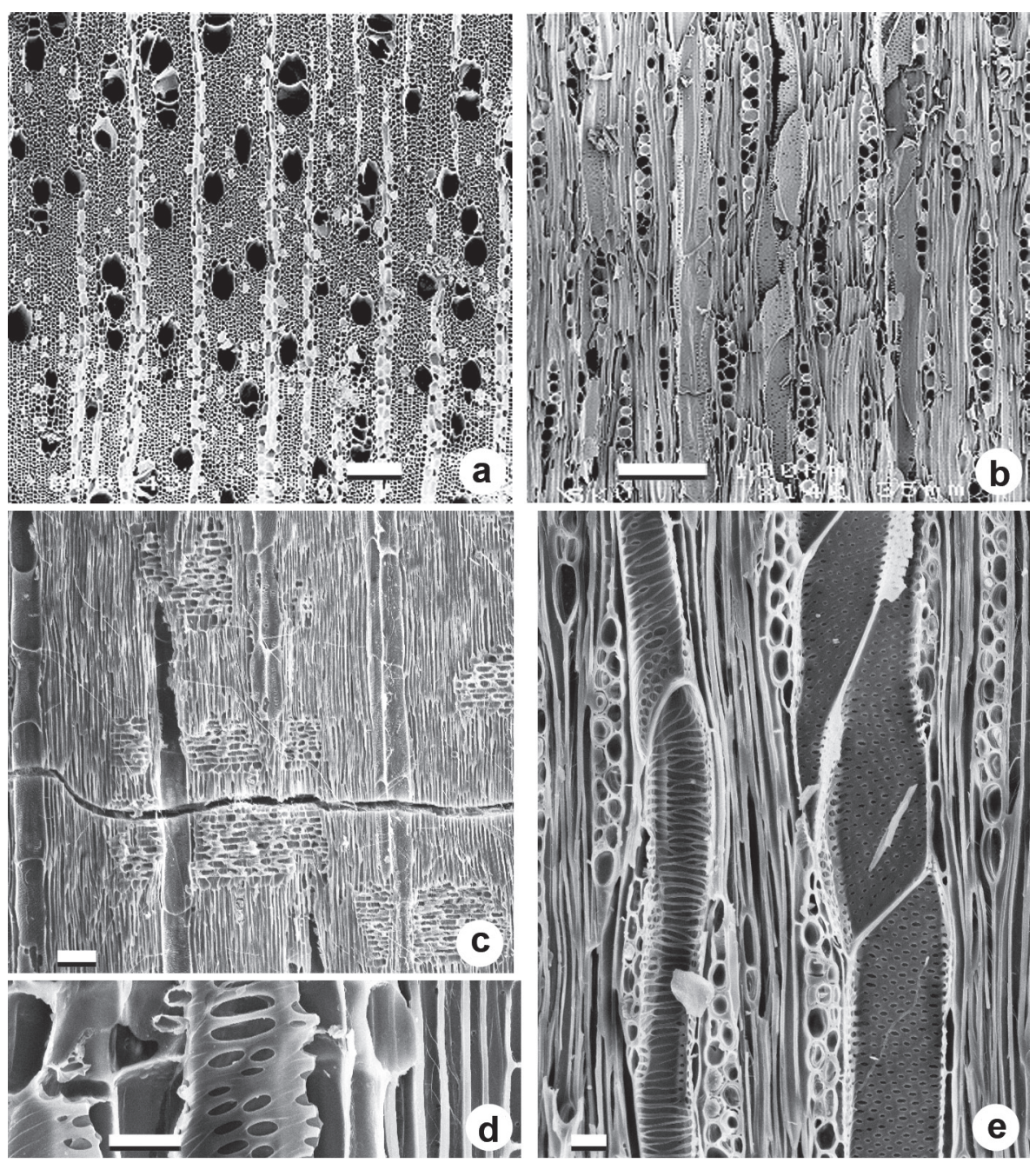

Figure 3. Lithrea molleoides (USPw 520). Platinum-coated, UM-II (a-b), gold-coated, CETEM (c-e). - a: Transverse section. - b: Tangential section. - c: Radial section. - d: Vessel-ray pits. - e: Spiral thickenings in some vessels. Bars $=100 \mu \mathrm{m}(\mathbf{a - c})$ and $20 \mu \mathrm{m}(\mathbf{d}-\mathbf{e})$.

to apparently simple, rounded. Axial parenchyma: scanty paratracheal, fairly distinct, in 2-4-celled strands. Rays: 2-3-seriate in S. purpurea, 3-6-seriate in S. tuberosa, and 4-7-seriate in S. mombin; 5(2-8) rays/mm; procumbent body cells with 1-4, rarely up to 6 rows of upright marginal cells. Fibres: septate with simple to slightly bordered pits and very thin-walled. Secretory elements: radial canals with tangential diameter $40(20-80) \mu \mathrm{m}$. Mineral inclusions: prismatic crystals in ray cells of $S$. purpurea and $S$. tuberosa and in fibres of $S$. tuberosa.

Tapirira Aubl. (Fig. 4 e-g)

Material studied: T. obtusa (Benth.) J.D.Mitch. (São Paulo, Brazil - BCTw 3863); T. guianensis Engl. (Alagoas, Brazil - RBw 5992, Santa Catarina, Brazil - SPSFw 300).

Growth rings: boundaries marked by thick-walled fibres in late wood in $T$. obtusa, indistinct or absent in T. guianensis. Vessels: wood diffuse-porous; solitary (50\%) and in multiples of 2 (27\%), 3 (18\%), and 4 (5\%); tangential diameter $90(60-140) \mu \mathrm{m}$; 20(10-30) vessels $/ \mathrm{mm}^{2}$; tyloses usually present; perforation 


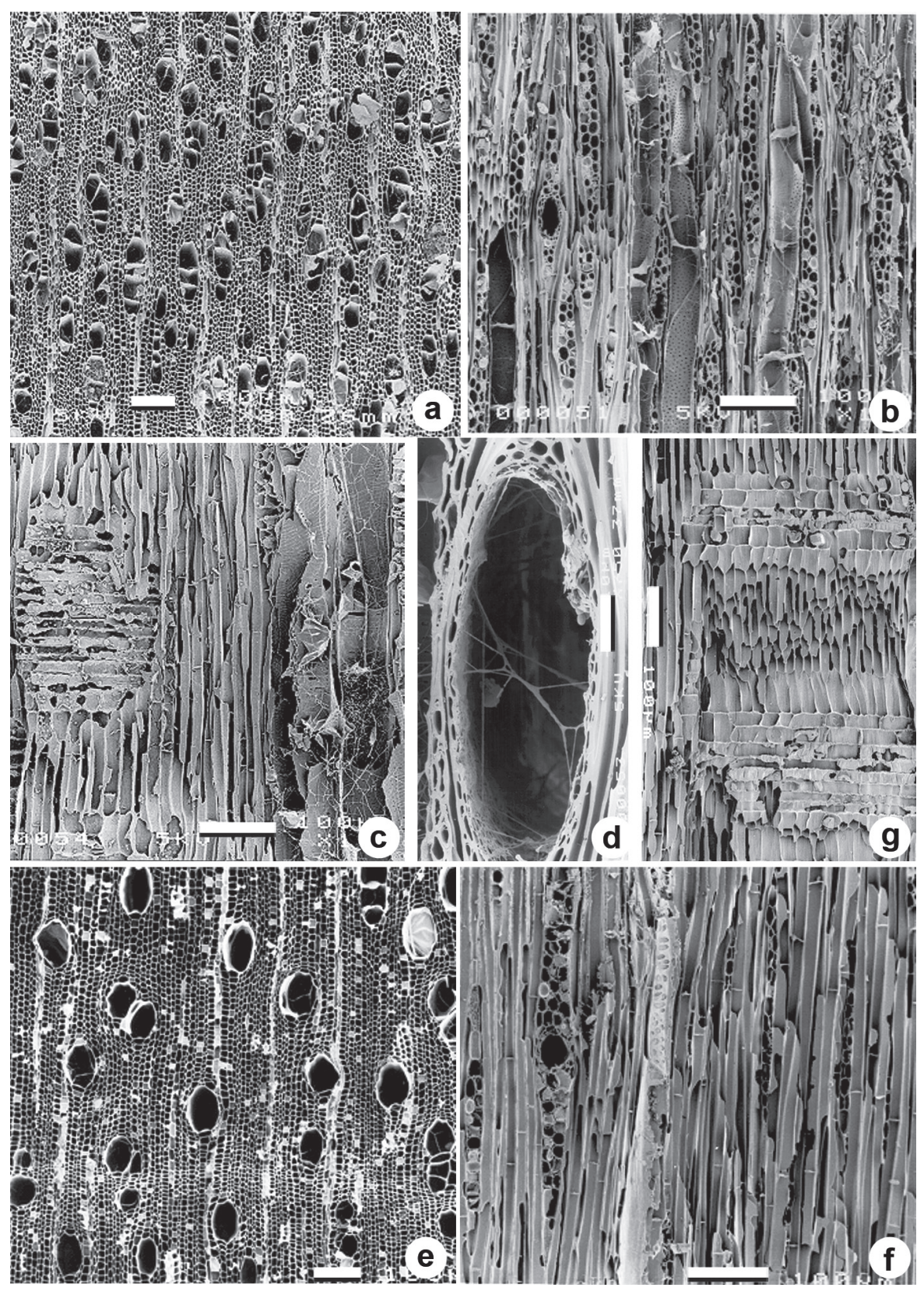

Figure 4. a-d. Schinus terebinthifolius (SPSFw 479). - e-g. Tapirira obtusa (BCTw 3863). Platinum-coated, UM-II. - a,e: Transverse section. - b,f: Tangential section. - c,g: Radial section. - d: Radial canal. - Bars $=100 \mu \mathrm{m}(\mathbf{a - c}, \mathbf{e - g})$ and $20 \mu \mathrm{m}(\mathbf{d})$.

plates simple with oblique or horizontal end walls; intervessel pits alternate, 5(3-7) $\mu \mathrm{m}$; vessel-ray pits larger than intervessel pits, with much reduced borders to apparently simple, rounded; helical thickenings present. Axial parenchyma: scanty paratracheal, fairly distinct, in 2-3-celled strands. Rays: 1-2(3)-seriate in T. obtusa, 2-3-seriate in T. guianensis; 7(3-10) rays/mm; body ray cells procumbent with 1 to 5 rows of upright marginal cells. Fibres: septate fibres with simple to slightly bordered pits, very thin-walled. Secretory elements: radial canals with tangential diameter 30(10-60) $\mu \mathrm{m}$. Mineral inclusions: prismatic crystals in ray cells. 


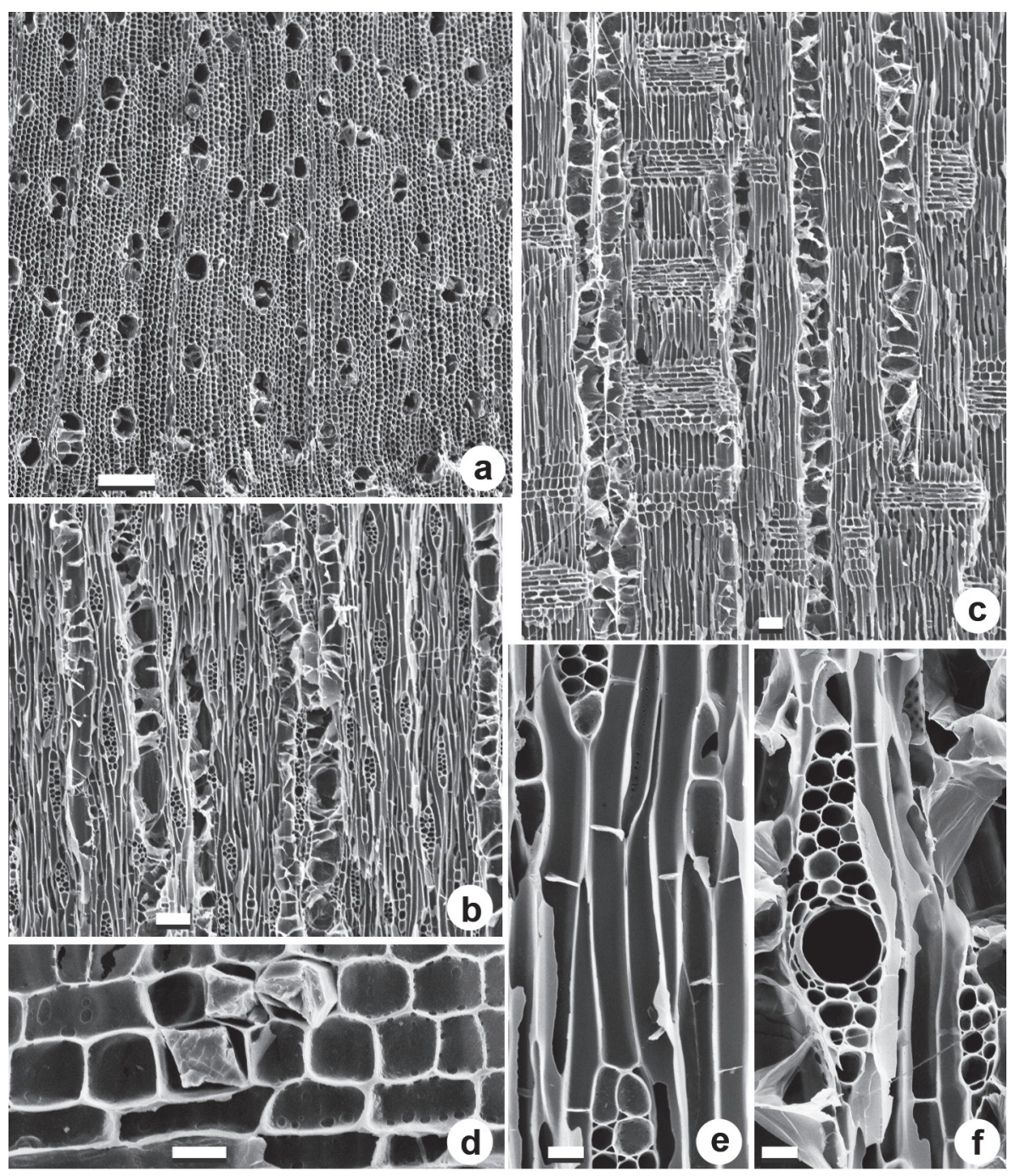

Figure 5. Spondias mombin (ME 201). Gold-coated, CETEM. - a: Transverse section. - b: Tangential section. - c: Radial section. - d: Prismatic crystals in ray cells. - e: Septate fibres. - f: Radial canal. Bars $=100 \mu \mathrm{m}(\mathbf{a}-\mathbf{c})$ and $20 \mu \mathrm{m}(\mathbf{d}-\mathbf{f})$.

TABLE I

Number of specimens analyzes and synthesis of the charcoal anatomical features for the studied Anacardiaceae species.

\begin{tabular}{|c|c|c|c|c|c|c|c|c|c|c|c|}
\hline Spec & 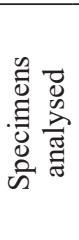 & 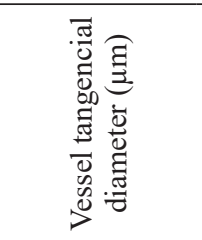 & 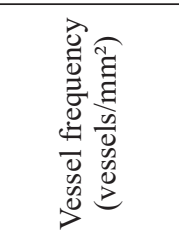 & 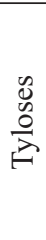 & 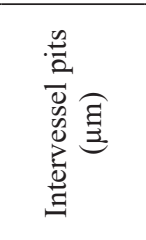 & 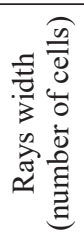 & 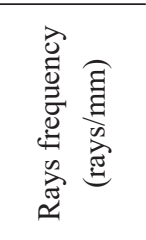 & 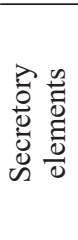 & 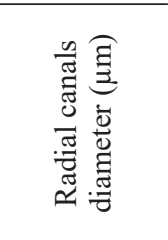 & 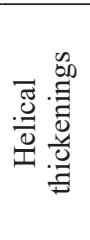 & 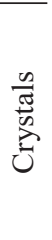 \\
\hline dium occide & 1 & $160(110-2$ & $0(6-14)$ & + & 5,5 & $1-2$ & $0(9-13)$ & - & - & - & - \\
\hline Anacardium parvifolium & 1 & $190(140-260)$ & $6(4-7)$ & - & $8(7$ & 1 & $11(10-12)$ & - & - & - & - \\
\hline Astronium graveolens & 4 & $(40-100)$ & $(12-2$ & + & 5( & $1-3$ & $9(7-11)$ & + & $0(30-7$ & - & + \\
\hline Astronium lecointei & 1 & $115(100-130)$ & $5(13-1$ & + & $5(4$ & 1(2) & $7(6-10)$ & + & $20(10-30)$ & - & + \\
\hline Lithrea molleoides & 3 & $45(20-80)$ & $68(25-110)$ & - & $3,5(3-5)$ & $1-3$ & $9(5-13)$ & - & - & + & + \\
\hline Schinus terebenthifolius & 6 & $50(20-100)$ & $130(70-230)$ & + & $3,5(2-6)$ & $1-3$ & $10(5-15)$ & + & $50(30-100)$ & + & + \\
\hline
\end{tabular}


TABLE I (continuation)

\begin{tabular}{|c|c|c|c|c|c|c|c|c|c|c|c|}
\hline Feature & 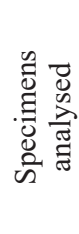 & 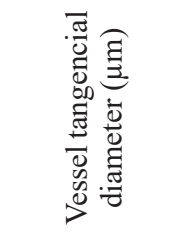 & 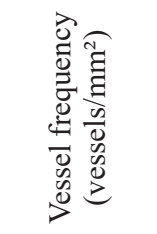 & \begin{tabular}{l}
0 \\
0 \\
0 \\
\multirow{2}{*}{}
\end{tabular} & 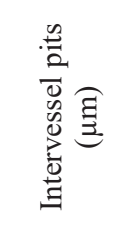 & 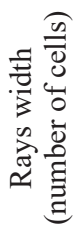 & 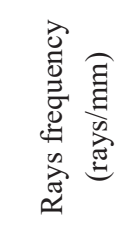 & 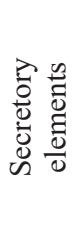 & 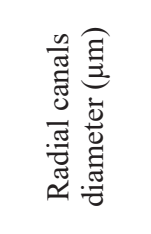 & 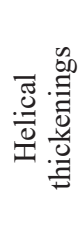 & 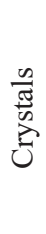 \\
\hline Spondias mombin & 1 & $30(70-210)$ & $0(7-30)$ & - & 6,5 & $4-7$ & $5(2-7)$ & + & $35(20-50)$ & - & + \\
\hline Spondias purpurea & 1 & $100(60-14$ & $0(13-30)$ & $(+)$ & $7(6-8)$ & $2-3$ & $6(4-8)$ & + & $30(20-40)$ & - & + \\
\hline Spondias tuberosa & 2 & $140(50-250)$ & $5(7-20)$ & $(+)$ & 7( & $3-6$ & $5(3-8)$ & + & $40(20-80)$ & - & + \\
\hline Tapirira guianensis & 2 & $110(60-140)$ & $15(10-20)$ & + & $5(3-7)$ & $2-3$ & $7(4-10)$ & + & $40(20-60)$ & + & + \\
\hline Tapirira obtusa & 1 & $80(50-110)$ & $25(23-30)$ & + & $5,5(4-7)$ & $1-2$ & $6,5(3-9)$ & + & $20(10-30)$ & + & + \\
\hline
\end{tabular}

+: present; (+): rare; -: absent.

Even if vessels tangential diameter and frequency may sometimes differ, it is not possible to distinguish the studied species through charcoal anatomy. Genera, however, or groups of species, can be distinguished by considering a combination of features such as radial canals, helical thickenings, rays width, vessels diameter, and vessels frequency, as proposed in the dichotomous key below. Features such as diameter of intervessel pit apertures and rays frequency do not vary significantly, while the presence of tyloses may depend on the part of the stem analyzed, and that of crystals on environmental aspects. Those are not reliable diagnostic characters, but can be useful to ascertain the identification.

\section{Dichotomous key}

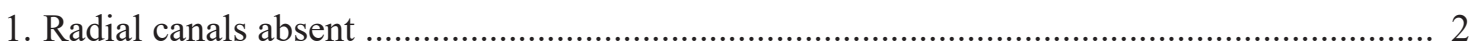

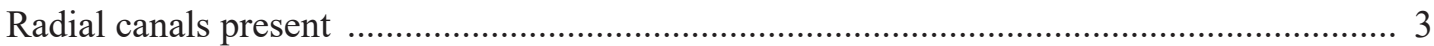

2. Mean vessel tangential diameter less than $50 \mu \mathrm{m}$, more than 40 vessels $/ \mathrm{mm}^{2}$............. Lithrea Mean vessel tangential diameter more than $100 \mu \mathrm{m}$, less than 20 vessels $/ \mathrm{mm}^{2}$..... Anacardium

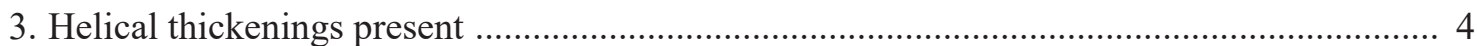

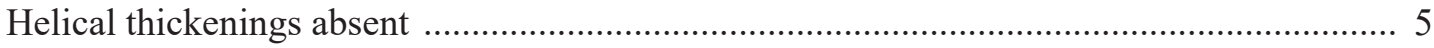

4. Mean vessel tangential diameter less than $50 \mu \mathrm{m}$, more than 100 vessels $/ \mathrm{mm}^{2}$.......... Schinus Mean vessel tangential diameter more than $50 \mu \mathrm{m}$, less than 40 vessels $/ \mathrm{mm}^{2}$

Tapirira

5. Rays 1-3-seriate 6 Rays more than 3-seriate Spondias mombin, Spondias tuberosa

6. Rays 1-3-seriate Astronium Rays 2-3-seriate Spondias purpurea

\section{DISCUSSION}

Anatomical description of charcoal samples intends to improve taxonomical identification and to provide better comparative material to charcoal identification in tropical regions. The decision of describing charcoal 
is due to methodological requirements. Charcoal analysis in reflected-light microscopy is technically easier and much less time-consuming than traditional techniques of wood analysis involving slides preparation.

Besides, we highlight the unequivocal advantage of comparing similar materials. Charcoal identification is much more effective when unknown samples are compared to charred extant equivalents, instead of to wood slides. This happens not only because of easiness of observation, but also in reason of minor anatomical changes due to carbonization. As a rule, wood structure is very well preserved after carbonization, but some modifications may occur, such as: homogenization of the cell walls; tangential and radial shrinkage (which may induce small changes in vessels diameter and in the size of axial and radial parenchyma cells); and disappearance or modification in cell contents (Prior and Gasson 1993, Kim and Hanna 2006, Gonçalves et al. 2012).

Anatomical characteristics of Brazilian Anacardiaceae charcoal are, as in wood, relatively homogeneous, but the different genera studied can be distinguished through wood anatomy. The present results closely agree with general descriptions of Anacardiaceae wood (Record and Hess 1943, Metcalfe and Chalk 1950) and with generic and specific wood descriptions (e.g. Tortorelli 1956, Mainieri 1958, Kribs 1968, Pérez Olvera et al. 1980, Martijena 1987, Barajas-Morales and Gómez 1989, Fedalto et al. 1989, Mainieri and Chimelo 1989, Terrazas and Wendt 1995, Richter and Dallwitz 2000, Barros et al. 2001, Miller 2007, Gupta and Agarwal 2008). In most cases, qualitative and quantitative data from the carbonized samples are very similar to previously published studies in wood anatomy, e.g. for Anacardium occidentale (Hess 1946, Dechamps 1979, Détienne and Jacquet 1983, Dong and Baas 1993), Astronium graveolens (Détienne and Jacquet 1983, Nardi Berti and Edlmann Abbate 1992), Lithrea spp (Hess 1946, Terrazas 1994), Lithrea molleoides (Pinho 1969), Schinus spp (Hess 1946, Jofre 1988, Terrazas 1994), Schinus terebinthifolius (Tavares 1970), Spondias spp (Williams 1936, Hess 1946, Kryn 1952, Détienne and Jacquet 1983, Dong and Baas 1993, Terrazas 1994, Sosef et al. 1998), Spondias mombin (León 2003), Tapirira spp (Hess 1946, Terrazas 1994), Tapirira guianensis (Williams 1936, Dechamps 1979). This is particularly interesting for, in spite of morphometrical changes due to the carbonization process (Mc Ginnes et al. 1971, Prior and Alvin 1986, Prior and Gasson 1993, Gonçalves et al. 2012), wood anatomical features seem directly comparable between carbonized and non-carbonized samples.

In other cases, however, a few features differed from these previous descriptions, especially regarding vessels tangential diameter and frequency - e.g., in Astronium graveolens vessels are $140 \%$ smaller and $80 \%$ more frequent, and in Astronium lecontei $75 \%$ smaller and $60 \%$ more frequent than it was reported by Dechamps (1979); in Schinus terebinthifolius vessels are 60\% more frequent than reported by Tavares (1970); in Spondias mombin vessels are 10\% smaller than reported by León (2003); in Spondias purpurea vessels are 100\% smaller and more frequent than reported by Barajas-Morales and Gómez (1989); in Tapirira guianensis vessels are 60\% more frequent than reported by Dechamps (1979).

Intervessel pits are generally smaller than reported in the literature, but the data reported for noncarbonized wood refer to the diameter of chamber, while in this work we have measured pit apertures.

Quantitative variation, particularly lower vessels tangential diameter, and higher vessels frequency, can be explained by the carbonization process, but intraspecific variability and/or ecological factors can also be implied.

\section{CONCLUSIONS}

Anatomical description of charcoal aims to improve taxonomical identification and to provide better means to anthracological studies in the tropics. 
Descriptions of tropical charcoal anatomy are of utmost importance in different fields of knowledge, such as archaeobotany, palaeoecology, wood technology, and environmental conservation. They are most important as a comparative material for the identification of unknown charcoal pieces from archaeological or sedimentary contexts, which may lead to palaeoenvironmental and palaeoethnobotanical interpretations.

The use of anthracology to control illegal charcoal commerce also shows a strong potential in Brazil. There are as yet few studies with charcoal intended to reduce the indiscriminate use of native species, but they are generally focused in Eucalyptus, which is the most frequently species legally used for charcoal production (e.g. Botrel et al. 2007, Gonçalves et al. 2014). This is the first attempt to directly describe the anatomy of charcoal samples aiming to contribute to the construction of a database that might eventually contribute to prevent the continuity of deforestation and help the sustainability of the charcoal supply chain. The use of anthracology to control illegal charcoal commerce is, therefore, a particularly important application of the present work.

Additionally, this work may contribute to a better knowledge of wood anatomy of native tropical species, which is still incompletely known. Indeed, while this is the first time that charcoal anatomy descriptions are presented for all the studied species, two species are here described for the first time both in charcoal as in conventional wood anatomy: Anacardium parvifolium Ducke and Spondias tuberosa Arruda.

\section{ACKNOWLEDGMENTS}

We are grateful to Dr. Carmen R. Marcatti (UNESP, Botucatu), Dr. Kishore S. Rajput (M.S. University of Baroda, India), and two anonymous referees for their most useful comments and advice. We are also thankful to Geraldo J. Zenid (BCTw), Catia Callado (RBw), Onildo Barbosa (SPSFw), and Maria Eugenia Solari (Valdivia, Chile), who provided wood samples for this study. This work was supported by grants from the Conselho Nacional de Desenvolvimento Científico e Tecnológico (CNPq, Brazil) and Fundação Carlos Chagas Filho de Amparo à Pesquisa do Estado do Rio de Janeiro (FAPERJ, Brazil).

\section{RESUMO}

Estudos antracológicos têm tido avanço significativo nos trópicos nas últimas décadas. As bases teóricas e metodológicas da disciplina estão bem estabelecidas, entretanto, existe ainda uma forte demanda por material comparativo de referência visando melhorar a acurácia nas determinações taxonômicas, tanto em estudos paleoecológicos e paleoetnobotânicos como para contribuir com o controle da produção ilegal de carvão vegetal. Este trabalho apresenta descrições da anatomia do lenho carbonizado de 11 espécies de Anacardiaceae, em seis gêneros nativos do Brasil (Anacardium occidentale, Anacardium parvifolium, Astronium graveolens, Astronium lecointei, Lithrea molleoides, Schinus terebenthifolius, Spondias mombin, Spondias purpurea, Spondias tuberosa, Tapirira guianensis e Tapirira obtusa). Elas são caracterizadas por vasos de arranjo difuso, solitários e múltiplos, algumas vezes com tiloses e espessamentos espiralados; placas de perfuração simples, pontoações intervasculares alternas, pontoações raiovasculares maiores que as intervasculares; raios heterocelulares, podendo apresentar canais radiais e cristais; fibras septadas com pontoações simples ou aréolas reduzidas. Os resultados obtidos são similares a descrições prévias de anatomia da madeira das mesmas espécies ou gêneros. Ainda assim, a identificação de carvões é muito mais eficiente quando as amostras desconhecidas são comparadas a equivalentes atuais carbonizados, ao invés de lâminas finas.

Palavras-chave: antracologia, arqueobotânica, carvão, paleoecologia, conservação da natureza, anatomia da madeira.

\section{REFERENCES}

ABRAF. 2009. Anuário estatístico da ABRAF 2009: ano base 2008. Brasília: ABRAF - Associação Brasileira de Produtores de Florestas Plantadas. In: http://www.bibliotecaflorestal.ufv.br/handle/123456789/3905. 
ABRAF. 2013. Anuário estatístico da ABRAF 2013: ano base 2012. Brasília: ABRAF - Associação Brasileira de Produtores de Florestas Plantadas. In: http://www.bibliotecaflorestal.ufv.br/handle/123456789/3910.

AlBuQuerque AR. 2012. Anatomia comparada do lenho e do carvão aplicada na identificação de 75 espécies da floresta Amazônica, no estado do Pará, Brasil. Unpublished Dissertation. Escola Superior de Agricultura "Luiz de Queiroz", Universidade de São Paulo, Brasil.

Barajas-Morales J And Gómez CL. 1989. Anatomia de Maderas de Mexico: Especies de una selva baja caducifolia. Universidad Nacional Autónoma de México.

BARros CF AND CALlado CH. 1997. Madeiras da Mata Atlântica: Anatomia do lenho de espécies ocorrentes nos remanescentes florestais do Estado do Rio de Janeiro, Brasil. Vol. I. Rio de Janeiro: Jardim Botânico do Rio de Janeiro.

Barros CF, Callado CH, Cunha M, Marcon-Ferreira ML, Tamaio N, Marquete O and Costa CG. 2008. Madeiras da Mata Atlântica: Anatomia do lenho de espécies ocorrentes nos remanescentes florestais do estado do Rio de Janeiro, Brasil. Vol. III. Rio de Janeiro: Instituto de Pesquisas Jardim Botânico do Rio de Janeiro.

Barros CF, Callado CH, Marcon ML, Costa CG, Cunha M, Lima HrP and Marquete O. 2001. Madeiras da Mata Atlântica: Anatomia do lenho de espécies ocorrentes nos remanescentes florestais do Estado do Rio de Janeiro, Brasil. Vol. II. Rio de Janeiro: Instituto de Pesquisas Jardim Botânico do Rio de Janeiro.

BLANKENHORN PR, JENKINS GM AND KLINE D. 1972. Dynamic mechanical properties and microstructure of carbonized hardwoods. Wood Fiber 4(3): 212-224.

Botrel MCG, TRUGILHO PF, Rosado SCS AND SILVA RM. 2007. Melhoramento genético das propriedades do carvão vegetal de Eucalyptus. Rev Árvore 31(3): 391-398.

BRASIL. 2012. Balanço energético nacional 2012: ano base 2011. Rio de Janeiro: Empresa de Pesquisa Energética. Ministério de Minas e Energia. In: https://ben.epe.gov.br/downloads/Relatorio_Final_BEN_2012.pdf.

CARNEIRO MS. 2008. Crítica social e responsabilização empresarial: análise das estratégias para a legitimação da produção siderúrgica na Amazônia Oriental. Cad CRH 21(53): 323-336.

CHABAL L. 1997. Forêts et Sociétés en Languedoc (Néolithique Final, Antiquité Tardive). L'Anthracologie, Méthode et Paleoécologie. Doc archéol franç 63: 1-188.

CutTer BE, CUMBIE BG AND MCGINNES A. 1980. SEM and shrinkage analyses of Southern Pine wood following pyrolysis. Wood Sci Techn 14: 115-130.

DECHAMPS R. 1979. Étude anatomique de bois d'Amérique du Sud. Volume I. Acanthaceae à Lecythidaceae. Tervuren: Musée Royal de l'Afrique Centrale.

DÉTIENNE P AND JACQUET P. 1983. Atlas d'Identification des bois de l'Amazonie et des régions voisines. Montpellier: Centre Technique Forestier Tropical.

Dong Z AND BAAS P. 1993. Wood Anatomy of Trees and Shrubs from China. V. Anacardiaceae. IAWA J 14(1): 87-102.

FAO. 2014. FAOSTAT - Forestry Data. FAO - Food and Agriculture Organization of the United Nations. In: http://faostat3.fao. org/faostat-gateway/go/to/home/E.

FEDAlto LC, MENDES IC AND CORADIN VTR. 1989. Madeiras da Amazonia: Descrição do lenho de 40 espécies ocorrentes na Floresta Nacional do Tapajós. Brasília: Inst. Bras. Meio Ambiente e Rec. Nat. Renov. IBAMA.

FRIEDERICHS G, BRAND MA, CARVALHO AF AND KÜSTER LC. 2015. Qualidade da madeira e do carvão vegetal de bracatinga (Mimosa scabrella Benth.). Ciênc Madeira 6: 79-87.

GONÇALVES TAP. 2006. Contribuição ao conhecimento da anatomia da lenho das famílias Anacardiaceae, Annonaceae, Aquifoliaceae, Apocynaceae e Araliaceae, através de amostras carbonizadas do lenho de espécies brasileiras. Unpublished Monography. Graduação em Engenharia Florestal, Universidade Federal Rural do Rio de Janeiro, Brasil.

GONÇALVES TAP. 2010. Modificações estruturais decorrentes da carbonização no lenho de espécies arbóreas do cerrado no estado de São Paulo, Brasil. Unpublished Dissertation. Faculdade de Ciências Agronômicas, Universidade Estadual Paulista, Brazil.

GONÇALVES TAP, BALLARIN AW, NISGOSKI S AND MUÑIZ GIB. 2014. A contribution to the identification of charcoal origin in Brazil. I - Anatomical characterization of Corymbia and Eucalyptus. Maderas, Cienc Tecnol 16(3): 323-336.

GONÇALVES TAP AND SCHEEL-YBERT R. 2012. Contra o carvão ilegal: estudo da anatomia da madeira pode ajudar a salvar florestas nativas. Ciência Hoje 292: 74-76.

GONÇALVES TAP, MARCATI CR AND SCHEEL-YBERT R. 2012. The effect of carbonization on wood structure of Dalbergia violacea, Stryphnodendron polyphyllum, Tapirira guianensis, Vochysia tucanorum, and Pouteria torta from the Brazilian cerrado. IAWA J 33: 73-90.

GREGUSS P. 1959. Holzanatomie der Europäischen Laubhölzer und Sträucher. Budapest: Akad. Kiadó, 330 p.

GUPTA S AND AGARWAL M. 2008. Wood anatomy of Anacardiaceae from India with special reference to the systematic position of Rhus. IAWA J 29: 79-106. 
HESS RW. 1946. Identification of New World Timbers. Part II - Anacardiaceae. Trop Woods 87: 11-34.

IAWA COMMITTEE. 1989. IAWA list of microscopic features for hardwood identification. IAWA Bull 10(3): $219-332$.

IBGE. 2010. Produção da extração vegetal e da silvicultura. Rio de Janeiro: IBGE - Instituto Brasileiro de Geografia e Estatística. 25: 50.

IOS. 2011a. A floresta que virou cinza. 31 p. Instituto Observatório Social. In: $<$ http://uc.socioambiental.org/sites/uc.socioambiental. org/files/revista_obs1.pdf>

IOS. 2011b. O aço da devastação. 33 p. Instituto Observatório Social. In: <http://www1.ethos.org.br/EthosWeb/arquivo/0-A620Pesquisa_A\%20Devasta $\%$ C3\%A7\%C3\%A3o\%20do\%20A\%C3\%A7o.pdf>

JOFRE MM. 1988. Estudio anatomico de las especies: Schinus latifolius (Molle) \& Schinus molle (Pimiento). Depto. Tecnologia de la Madera, Universidad de Chile.

KIM NH AND HANNA RB. 2006. Morphological characteristics of Quercus variabilis charcoal prepared at different temperatures. Wood Sci Techn 40: 392-401.

KRIBS DA. 1968. Commercial foreign woods on the American market. New York: Dover Publications, $241 \mathrm{p}$.

KRYN JM. 1952. The anatomy of the wood of the Anacardiacae and its bearing on the phylogeny and relationships of the family. Unpublished PhD thesis, University of Michigan, United States.

LEÓN WJH. 2003. Estudio anatómico del xilema secundario de 17 especies de la familia Anacardiaceae en Venezuela. Acta Bot Venez 26: 1-30.

MC GINNES EA, KANDEL SA AND SzOPA PS. 1971. Some structural changes observed in the transformation of wood into charcoal. Wood Fiber 3(2): 77-83.

MAINIERI C. 1958. Madeiras denominadas Caixeta. Inst. Pesq. Tec., São Paulo, n. 572.

MAINIERI C AND CHIMELO JP. 1989. Fichas de características das madeiras brasileiras. $2^{\mathrm{a}}$ ed., IF, São Paulo.

MARTIJENA N. 1987. Wood anatomy of Lithrea ternifolia (Gill.) Barkley \& Rom. (Anacardiaceae). IAWA Bull 8: 47-52.

METCALFE CR AND CHALK L. 1950. Anatomy of dicotyledons. Oxford: Clarendon Press.

MILLER RB. 2007. Fluorescent woods of the world. In: Flynn JH (Ed), A Guide to the More Useful Woods of the World. Madison: Forest Products Society, p. 271-305.

NARDi BERTI R AND ELDMANN ABBATE ML. 1992. Legnami tropicali importati in Italia: anatomia e identificazione. Vol. II. America Latina. Firenze: CNR.

PAULA JE AND ALVES JL. 1997. Madeiras Nativas: Anatomia, dendrologia, dendrometria, produção e uso. Fundação MOA, Brasília.

PÉREZ OlVERA CP, VALDOVINOS CTF AND GÓMEZ MAR. 1980. Estudio anatomico de la Madera de 43 especies tropicales. Bol Téc Inst Nac Invest For, n.63.

PINHO RA. 1969. Contribuição ao Estudo Anatômico do Lenho Secundário de Árvores da Flora dos Cerrados - II. Arq Bot Estado de São Paulo 4: 4-6.

PINTO AA. 2013. Anatomia do Lenho Carbonizado de 10 Espécies Nativas da Planície Costeira do Rio Grande do Sul como Subsídio a Pesquisas Arqueobotânicas e Paleoecológicas. Unpublished Monography. Graduação em Arqueologia, Instituto de Ciências Humanas e da Informação, Universidade Federal do Rio Grande, Brasil.

PRIOR J AND ALVIN KL. 1986. Structural changes on charring woods of Dichrostachys and Salix from Southern Africa: The effect os moisture content. IAWA Bull 7(3): 243-262.

PRIOR J AND GASSON P. 1993. Anatomical changes on six African hardwoods. IAWA J 14(1): 77-86.

RECORD SJ AND HeSS RW. 1943. Timbers of the New World. Yale: Univ. Press, N. Haven, 640 p.

RICHTER HG AND DALLWITZ MJ. 2000 onwards. Commercial timbers: descriptions, illustrations, identification, and information retrieval. In English, French, German, Portuguese, and Spanish. Version: June 2009. In: http://delta-intkey.com

SCHEEL-YBERT R. 2004a.Teoria e métodos em Antracologia. 1. Considerações teóricas e perspectivas. Arq Mus Nacional 62(1): 3-14.

SCHEEL-YBERT R. 2004b. Teoria e métodos em Antracologia. 2. Técnicas de campo e de laboratório. Arq Mus Nacional 62(4): 343-356.

SCHEEL-YBERT R AND GONÇALVES TAP. In press. Primeiro Atlas Antracológico de Espécies Brasileiras / First Anthracological Atlas of Brazilian Species. Rio de Janeiro: Museu Nacional.

SCHWEINGRUBER FH. 1990. Anatomy of European woods. Bern/Stuttgart: P. Haupt.

SCOTT AC AND DAMBLON F. 2010. Charcoal: Taphonomy and significance in geology, botany and archaeology. Palaeogeogr Palaeoclimat Palaeoecol 291: 1-10.

SOLARI ME. 1993. L'Homme et le bois en Patagonie et Terre de Feu au cours des six derniers millénaires: recherches anthracologiques au Chili et en Argentine. Unpublished PhD thesis, Université Montpellier-II, France. 
SONSIN JO, GASSON P, MACHADO SR, CAUM C AND MARCATI CR. 2014. Atlas da Diversidade de Madeiras do Cerrado Paulista / Atlas of Wood Diversity in the Cerrado of São Paulo. Botucatu: FEPAF.

Sosef MSM, Hong LT and PraWirohatModjo S (Eds). 1998. Plant Resources of South-East Asia. Leiden: Backhuys Publishers. SOUZA VC AND LORENZI H. 2008. Botânica Sistemática. Nova Odessa: Inst Plantarum.

TAVARES EJS. 1970. Anatomia do lenho de Schinus terebinthifolius Raddi. Bol Rec Nat SUDENE/DRN 8(1-2): 195-199.

TERRAZAS TS. 1994. Wood anatomy of the Anacardiaceae: ecological and phylogenetic interpretation. Unpublished dissertation, University of North Carolina, United States.

TERRAZAS TS AND WENDT T. 1995. Systematic wood anatomy of the genus Tapirira Aublet (Anacardiaceae): a numerical approach. Brittonia 47(2): 109-129.

TORTORELli LA. 1956. Maderas y bosques argentinos. Buenos Aires: Editorial Acme, 910 p.

Vernet JL, Ogereau P, Figueiral I, Machado Yanes C AND UZQUiano P. 2001. Guide d'identification des charbons de bois préhistoriques et récents: Sud-Ouest de l'Europe : France, Péninsule Ibérique et Îles Canaries. Paris: CNRS ed., 395 p.

WiLliams L. 1936. Woods of Northeastern Peru. Botanical Series v 15. Chicago: Field Museum of Natural History, 608 p. 